\title{
Corn hybrid silage quality according to harvesting time
}

\section{Qualidade da silagem de híbridos de milho em função do ponto de colheita}

\author{
Mikael Neumann ${ }^{1}$; Bruno José Venancio ${ }^{2 *}$; Egon Henrique Horst ${ }^{3}$; \\ Fernando Braga Cristo ${ }^{4}$; Karina Petkowicz ${ }^{5}$; Giovanna Bobato Pontarolo ${ }^{4}$; \\ Marcelo Cruz Mendes ${ }^{6}$; Maria Beatriz Antonietti Martins ${ }^{7}$
}

\begin{abstract}
Highlights:
Considering dry biomass production and fiber composition, is the best P30R50H.

The advance of the stages provided an increase in the grain participation.

R4 stage was the moment of best for silage production.
\end{abstract}

\begin{abstract}
The present study aimed to evaluate the dry matter production of different corn hybrids, the plant chemical composition at the time of ensiling and the participation of the structural components of the plant at the different phenological stages. Corn hybrids P2530, P30B39H and P30R50H were harvested successively at the kernel blister (R2); kernel milk (R3); kernel dough (R4); and kernel dent (R5) stages. We determined the dry matter contents, the percentage participation of each physical structure of the plant at the time of each evaluation, as well as the first ear height, plant height, number of dry leaves, production of dry ensilable phytomass, grain and chemical composition at the time of ensiling (kernel dent stage, R5). There was no difference $(\mathrm{p}>0.05)$ in dry phytomass production between the evaluated hybrids. In general, the hybrid P30R50H, considering dry biomass production and fiber composition of the plant and relative value of the food was balanced for silage. The advance of the stages provided an increase in the grain participation and consequent reduction of the other components in the physical composition of the plant, and the R4 stage was the moment of best association between productivity and physical composition of the plant for silage production.
\end{abstract}

Key words: Bromatology. Dry matter production. Phenological stages. Structural components. Total digestible nutrients.

1 Dr., Pesquisador, Núcleo de Produção Animal, NUPRAN, Prof., Pós-Graduação, Cursos de Agronomia e Ciências Veterinárias, Universidade Estadual Do Centro Oeste, UNICENTRO, Guarapuava, PR, Brasil. E-mail: neumann.mikael@hotmail.com

2 M.e em Ciências Veterinárias, Área de Saúde e Produção Animal Sustentável, UNICENTRO, Colaborador, Núcleo de Produção Animal, NUPRAN, Guarapuava, PR, Brasil. E-mail: bru.ze.venancio@gmail.com

3 Discente, Curso de Doutorado do Programa de Pós-Graduação em Ciência Animal, Universidade Estadual de Londrina, UEL, colaborador do NUPRAN, Londrina, PR, Brasil.E-mail: egonhh@yahoo.com.br

4 Discentes, Curso de Mestrado do Programa de Pós-Graduação em Ciências Veterinárias, UNICENTRO, Colaboradores do NUPRAN, Guarapuava, PR, Brasil. E-mail: fernandobragacristo@gmail.com; giovannabpontarolo@hotmail.com

5 Discente, Curso de Mestrado do Programa de Pós-Graduação em Zootecnia, Universidade Estadual de Ponta Grossa, UEPG, Colaboradora do NUPRAN, Ponta Grossa, PR, Brasil. E-mail: petkowicz@outlook.com

6 Prof., Pós-Graduação do Curso de Agronomia, UNICENTRO, Dr., Colaborador, NUPRAN, Guarapuava, PR, Brasil. E-mail: mcruzm@gmail.com

7 Discente, Curso de Graduação em Medicina Veterinária, Centro Universitário Campo Real, CAMPO REAL, Guarapuava, PR, Brasil. E-mail: biaantonieetti@gmail.com

* Author for correpondence 


\section{Resumo}

O objetivo do trabalho foi avaliar a produção de matéria seca de diferentes híbridos de milho, a bromatologia da planta no momento da ensilagem bem como a participação dos componentes estruturais da planta nos diferentes estádios fenológicos. Foram utilizados os híbridos de milho P2530, P30B39H e P30R50H, colhidos sucessivamente nas fases de grão leitoso(R2); grão pastoso(R3); grão farináceo(R4); e grão farináceo-duro (R5). Determinou-se os teores de matéria seca, a participação percentual de cada estrutura física da planta, na ocasião de cada avaliação, além da altura da inserção da primeira espiga e da planta, número de folhas secas, produção de fitomassa seca ensilável, de grãos e bromatologia no momento da ensilagem (fase de grão farináceo-duro, R5). Não houve diferença $(\mathrm{p}>0,05)$ na produção de fitomassa seca entre os híbridos avaliados. Em geral o híbrido P30R50H, considerando a produção de biomassa seca e composição fibrosa da planta e valor relativo do alimento mostrou-se equilibrado para silagem. $\mathrm{O}$ avanço dos estádios proporcionou aumento na participação de grãos e consequente redução dos demais componentes na composição física da planta, e o estádio R4 apresentou-se como o momento de melhor associação entre produtividade e composição física da planta para produção de silagem.

Palavras-chave: Bromatologia. Componentes estruturais. Estádios fenológicos. Nutrientes digestíveis totais. Produção de matéria seca.

\section{Introduction}

In Brazil, only a fraction of the cultivated corn is for silage production, implying the use of cultivars that are not generally specific for preserved food production. In this case, only grain production is considered without taking into account fiber quality and digestibility. This leads to the belief that the selection and studies on commercially available hybrids with potential for silage production are constantly needed, but these characteristics are not the focus of most breeding programs (Gabriel, 2015). Paziani et al. (2013) state that to achieve the desirable characteristics in a silage, it is necessary to evaluate the hybrids as to their adaptation, measuring mainly the grain and dry matter productivity, as well as their chemical characteristics.

Numerous changes and physiological processes occur throughout the crop cycle, promoting changes in nutritional value, from which some technologies can be used to minimize such losses during the ensiling process.

The harvesting time is crucial for the maximum productive and chemical utilization, respecting the phenological cycle of each specific hybrid (Oliveira et al., 2010). According to Neumann (2011), the stage affects the final quality of the food, and the dry matter content is the main factor related to the fermentation process and nutrient conservation.

As the physiological maturity of the plant progresses, there is also an increase in dry matter yield and a reduction in in vitro dry matter digestibility, thus limiting the use of the fiber portion in the rumen dynamics, in contrast there is greater starch deposition in the grains resulting in a silage with higher energy content. In this case, harvesting requires machinery adaptations to improve grain processing by exposing the endosperm and making more substrate available to the fermenting microorganisms (Marafon et al., 2015).

For Neumann, Nörnberg, Leão, Horst and Figueira (2017), the vegetative portion is of great importance in the final quality of the silage, which is mostly constituted by the NDF, and with the advancement of the vegetative stage, there is an increase in the deposition of lignified structures in the NDF, thus promoting a reduction in plant digestibility.

Therefore, this study aimed to evaluate the dry matter production of different corn hybrids, the plant chemical composition at the time of ensiling and the participation of the structural components of the plant in the different phenological stages. 


\section{Material and Methods}

The experiment was carried out at the Animal Production Center (NUPRAN, Núcleo de Produção Animal) facilities of the Agricultural and Environmental Sciences Sector of the Midwestern Paraná State University (UNICENTRO), in Guarapuava, State of Paraná. The climate of the region of Guarapuava is $\mathrm{Cfb}$ (humid mesothermal subtropical), without dry season, with cool summers and moderate winter according to the Köppen classification, at an altitude of approximately 1,100 $\mathrm{m}$, average annual rainfall of $1,944 \mathrm{~mm}$, average annual minimum temperature of $12.7^{\circ} \mathrm{C}$, average annual maximum temperature of $23.5^{\circ} \mathrm{C}$ and relative air humidity of $77.9 \%$ according to Instituto Agronômico do Paraná [IAPAR] (2000). Figure 1 illustrates the mean maximum and minimum temperatures $\left({ }^{\circ} \mathrm{C}\right)$ and the monthly sum of rainfall in $\mathrm{mm}$ per ten-day period ${ }^{-1}$ during the experimental period.

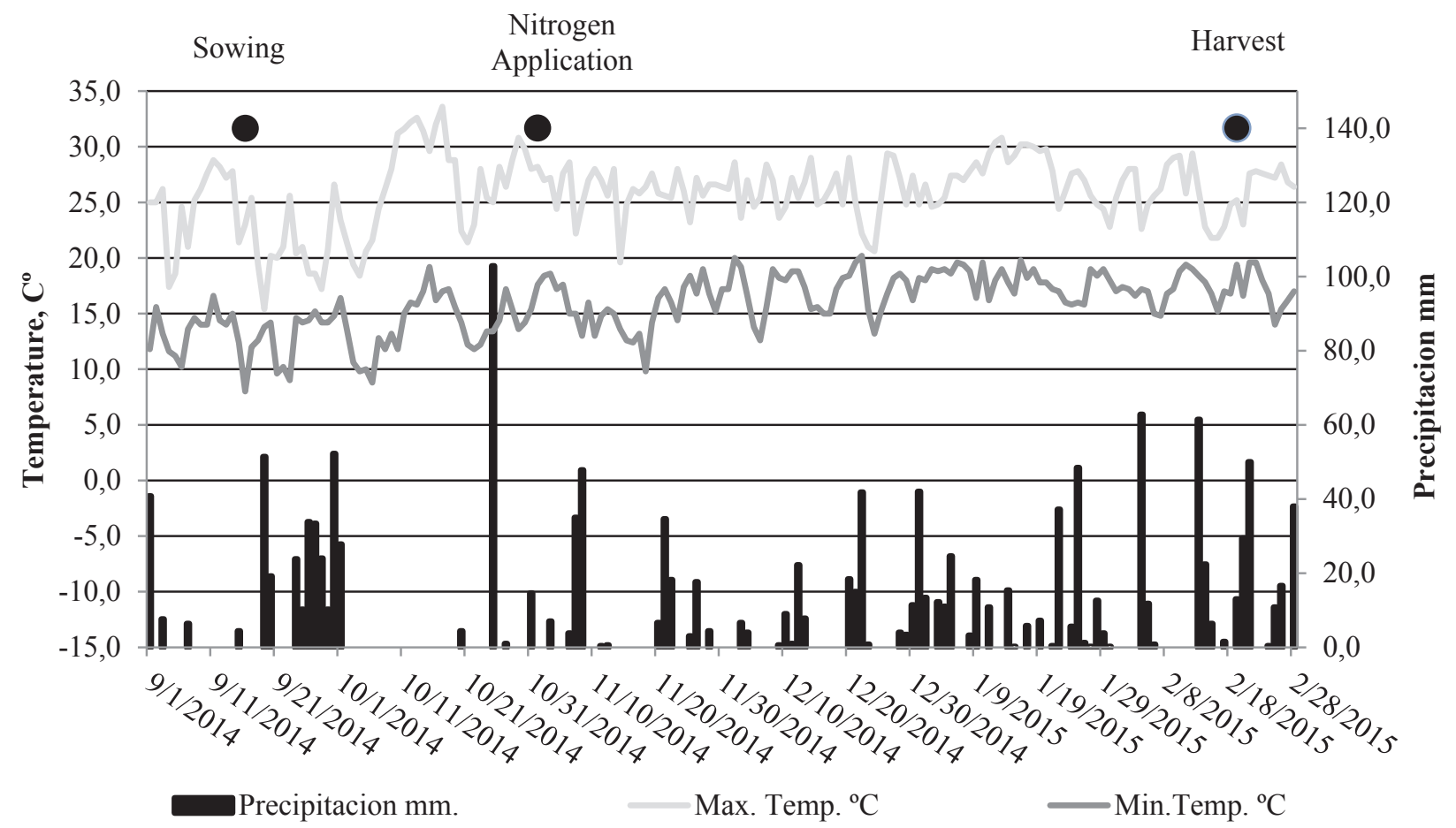

Source: SIMEPAR/UNICENTRO experimental station, Guarapuava, PR.

Figure 1. Mean maximum and minimum temperatures $\left({ }^{\circ} \mathrm{C}\right)$ and rainfall in $\mathrm{mm}$ per ten-day period ${ }^{-1}$ during the $^{-}$ experimental period.

The soil of the experimental area is classified as Dystroferric Red Latosol. The experimental area had been used in recent years with annual cycle pastures in the winter season, and corn crops in the summer season, receiving phosphorus and potassium fertilizers, according to the Fertilization and Liming Recommendations for the States of Rio Grande do Sul and Santa Catarina (Comissão de Fertilidade do Solo-RS/SC [CFS], 1995).
Experimental material consisted of the hybrids $\mathrm{P} 2530, \mathrm{P} 30 \mathrm{~B} 39 \mathrm{H}$ and $\mathrm{P} 30 \mathrm{R} 50 \mathrm{H}$, indicated by the company supplying genetics for silage production, because they have desirable characteristics for silage production as: high green mass yield potential per unit area $(>55 \mathrm{t} / \mathrm{ha})$; high participation of grains in plant structure $(>35 \%)$; versatile use and good adaptation to various regions and planting seasons, pronounced health of the vegetative portion, high 
production stability; low daily drying rate $(<0.5 \%$ day $\left.^{-1}\right)$; high concentration of total digestible nutrients ( $>65 \%)$; stem of medium thickness $(<3.5 \mathrm{~cm})$; plant height between 1.9 and $2.6 \mathrm{~m}$, low participation of bracts and cobs in the physical structure of the plant; pronounced stay-green and proven efficacy of animal performance.

Corn crops were planted in the second half of September in a no-till system, in succession to wheat, which was desiccated with a Glyphosatebased herbicide (Roundup WG commercial product: $1.5 \mathrm{~L} \mathrm{ha}^{-1}$ ).

Upon sowing, the row spacing was $0.8 \mathrm{~m}$, approximate sowing depth of $4 \mathrm{~cm}$ and seed distribution per linear meter aiming at a final population of 75 thousand plants $\mathrm{ha}^{-1}$, as indicated by the supplier. Corn hybrids were sown in plots with a total area of $20 \mathrm{~m}^{2}(4.0 \mathrm{~m} \times 5.0 \mathrm{~m})$. The useful area of $9.6 \mathrm{~m}^{2}$ (2.4 m x $\left.4.0 \mathrm{~m}\right)$ was used for evaluation.

The basal fertilization consisted of $40 \mathrm{~kg} \mathrm{ha}^{-1} \mathrm{~N}$ (Nitrogen), $100 \mathrm{~kg} \mathrm{ha}^{-1} \mathrm{P}_{2} \mathrm{O}_{5}$ and $100 \mathrm{~kg} \mathrm{ha}^{-1} \mathrm{~K}_{2} \mathrm{O}$, and as topdressing, $480 \mathrm{~kg} \mathrm{ha}^{-1} \mathrm{~N}$ was applied at the V5 stage. Corn crop management, up to 30 days after plant emergence, involved chemical weed control practices using a tembotrione-based herbicide (Soberan Commercial Product: 0.125 L $\mathrm{ha}^{-1}$ ) plus atrazine (Atrasina Commercial Product: $4 \mathrm{~L} \mathrm{ha}^{-1}$ ), as well as control of the fall armyworm (Spodoptera frugiperda) with a permethrin-based insecticide (Talcord commercial product, 0.100 $\mathrm{L} \mathrm{ha}^{-1}$ ) by technical report of the crops. The stand adaptation of the corn plants was carried out 15 days after emergence (DAE), manually, adjusting the plant population to 75 thousand plants $\mathrm{ha}^{-1}$.

The corn plants of the different hybrids were evaluated successively at the reproductive stages of kernel blister, R2; kernel milk, R3; kernel dough, R4; and kernel dent R5; according to the classification of Ritchie, Hanway and Benson (2003), to evaluate the dry matter accumulation of the plant and its structural components, as well as the characterization and participation of each structural component in the plant.

At each evaluation, 8 whole plants (original material) were harvested from the useful area of each plot, manually cut at $20 \mathrm{~cm}$ from the ground, at the time of each evaluation. The height of the first ear and the plant (m), number of dry leaves and production potential of the ensilable dry matter and the grain $\left(\mathrm{kg} \mathrm{ha}^{-1}\right)$, determined at the time of ensiling (kernel dent stage, R5) by composite samples of plants of plots relating individual weight of plants and plant population per unit area.

Samples of the whole plant and the structural components (leaf, stem, bracts plus cob and grains) of each treatment were obtained in a homogeneous and representative manner; weighed and predried in a forced air oven at $55^{\circ} \mathrm{C}$. After oven drying for 72 hours, they were weighed again for determination of dry matter (DM) content, according to the Association of Official Analytical Chemists [AOAC] (1984). They were then sent for grinding in a Wiley mill with a $1 \mathrm{~mm}$ diameter sieve.

Pre-dried samples were analyzed for total dry matter (DM) in an oven at $105^{\circ} \mathrm{C}$, crude protein (CP) by micro Kjeldahl method and mineral matter (MM) by incineration at $550^{\circ} \mathrm{C}$ (4 hours), according to AOAC (1995). We also determined the contents of Neutral detergent fiber (NDF), according to Van Soest, Robertson, and Lewis (1991), using thermostable $\alpha$ amylase (Termamyl 120L, Novozymes Latin America Ltda.) and acid detergent fiber (ADF) according to Goering and Van Soest (1970). Total digestible nutrient (TDN, \%) content was obtained via the equation [TDN, \% = 87.84 - (0.70 x ADF)] suggested by Bolsen (1996).

The experiment was conducted according to a completely randomized design with four replications and three treatments. For the morphological composition data, the following statistical model was adopted:

$$
Y_{i j}=\mu+\alpha_{i}+\beta_{j}+\gamma_{i j}+\varepsilon_{i j}
$$


where,

$$
\begin{aligned}
& \mathrm{Y}_{i j}=\begin{array}{l}
\text { Response variable related to hybrid } i \text { with } \\
\text { stage } j ;
\end{array} \\
& \mu=\text { Overall mean; } \\
& \alpha_{i}=\text { Effect of hybrid } i ; i=1,2,3 ; \\
& \beta_{j}=\text { Effect of stage } j ; j=1,2,3,4 ; \\
& \gamma_{i j}=\text { Effect of interaction of hybrid } i \text { with stage } j ; \\
& \varepsilon_{i j}=\quad \text { Random error associated with each } \\
& \quad \text { observation } \mathrm{Y}_{i j}
\end{aligned}
$$

For the data regarding plant height, ear height, number of dry leaves, production of dry phytomass and production of grains, and chemical composition, the following statistical model was adopted:

$$
Y_{i}=\mu+\alpha_{i}+\varepsilon_{i}
$$

where,

$$
\begin{aligned}
\mathrm{Y}_{i}= & \text { Response variable related to hybrid } i \\
\mu & =\text { Overall mean; } \\
\alpha_{i}= & \text { Effect of hybrid } i ; i=1,2,3 ; \\
\varepsilon_{i}= & \text { Random error associated with each } \\
& \text { observation } \mathrm{Y}_{i} .
\end{aligned}
$$

Data were subjected to Shapiro-Wilk and Bartlett tests to check the assumptions of normality and homogeneity of variance, respectively. Once these assumptions were met, the F-test was applied at 5\% confidence probability, using Analysis of Variance (ANOVA) and Tukey's test for comparison of multiple means at 5\% significance. Data were also subjected to polynomial regression analysis, considering the variable evaluation days, using the "proc reg" procedure of the SAS software (SAS Institute [SAS], 1993).

\section{Results and Discussion}

Higher values $(p<0.05)$ of plant height and ear insertion height were found in hybrids $\mathrm{P} 30 \mathrm{~B} 39 \mathrm{H}$, with $2.54 \mathrm{~m}$ and $1.46 \mathrm{~m}$, respectively, and $\mathrm{P} 2530$ with $2.53 \mathrm{~m}$ and $1.39 \mathrm{~m}$, respectively (Table 1 ). According to the classification of Pinto et al. (2010), all hybrids are midsized. It is noteworthy that the ears with very low insertion can result in grain production with poor sanitary condition. The evaluation of plant and ear height is essential as a parameter for choosing a corn silage hybrid, as they are directly related to the productivity of this hybrid (Lupatini, Maccari, Zanette, Piacentini, \& Neumann, 2004).

Very low ear height can result in production of grains with poor sanitary condition. The evaluation of plant and ear height is essential as a parameter for choosing a corn hybrid for silage, as they are directly related to the productivity of this hybrid (Lupatini et al., 2004).

There was no difference between hybrids for the number of dry leaves per plant at harvest, with results within the expectations for the stay green parameter, according to the methodology of Lupatini et al., (2004). According to Lupatini and Nunes (1999), it is desirable that at the time of harvest the number of dry leaves is equal to or less than 3. The overall average obtained for the number of dry leaves at harvest was similar to that recommended by Neumann, Figueira, Bumbieris, Ueno and Leão (2014), according to the same authors, this parameter is of great interest because it determines the time available for logistic ensiling operations, which directly influence the final quality of silage. Despite the differences in height between the hybrids, there was no difference for green and dry phytomass production, with mean values of $47,517 \mathrm{~kg} \mathrm{ha}^{-1}$ and $17,960 \mathrm{~kg} \mathrm{ha}^{-1}$, respectively, values below those presented by Rossi et al. (2016) who obtained a dry matter yield of $25,627 \mathrm{~kg} \mathrm{ha}^{-1}$ for the hybrid P30R50H in the region of Guarapuava, 
and similar to those of Lupatini et al. (2004), who evaluated several corn hybrids and obtained dry phytomass production ranging from $12,783 \mathrm{~kg} \mathrm{ha}^{-1}$ to $17,484 \mathrm{~kg} \mathrm{ha}^{-1}$.

Table 1

Plant height, first ear height, number of senescent leaves per plant, dry phytomass production and grain yield of different corn hybrids harvested at the R5 phenological stage.

\begin{tabular}{cccccc}
\hline Hybrid & $\begin{array}{c}\text { Plant height } \\
(\mathrm{m})\end{array}$ & $\begin{array}{c}\text { First ear } \\
\text { height }(\mathrm{m})\end{array}$ & $\begin{array}{c}\text { Number of senescente } \\
\text { leaves per plant }\end{array}$ & $\begin{array}{c}\text { Dry phytomass } \\
\text { prodution }\left(\mathrm{kg} \mathrm{ha}^{-1}\right)\end{array}$ & $\begin{array}{c}\text { Grain yield } \\
\left(\mathrm{kg} \mathrm{ha}^{-1}\right)\end{array}$ \\
\hline P2530 & $2,53 \mathrm{a}$ & $1,39 \mathrm{a}$ & $4,0 \mathrm{a}$ & $18.237 \mathrm{a}$ & $9.362 \mathrm{a}$ \\
$\mathrm{P} 30 \mathrm{~B} 39 \mathrm{H}$ & $2,54 \mathrm{a}$ & $1,46 \mathrm{a}$ & $5,0 \mathrm{a}$ & $17.815 \mathrm{a}$ & $7.789 \mathrm{~b}$ \\
P30R50H & $2,24 \mathrm{~b}$ & $1,27 \mathrm{~b}$ & $5,2 \mathrm{a}$ & $17.827 \mathrm{a}$ & $7.693 \mathrm{~b}$ \\
\hline Mean & 2,44 & 1,37 & 4,7 & 17.960 & 8.281 \\
P $>\mathrm{F}$ & 0,0677 & 0,0753 & 0,1076 & 0,4235 & 0,0080 \\
$\mathrm{CV}, \%$ & 5,81 & 5,97 & 12,72 & 4,02 & 6,19 \\
\hline
\end{tabular}

Neumann et al. (2014) stated that parameters such as plant and ear height have a direct correlation with the values of green and dry biomass production, differently from the present study. Ferrari Júnior, Possenti, Lima, Nogueira and Andrade (2005) reported that parameters such as plant height, grain yield and increased participation of structural components of the plant may be related to sowing done outside the recommended period for the crop.

Grain yield at harvest showed better results for the hybrid P2530, with 9,530 $\mathrm{kg} \mathrm{ha}^{-1}, 22 \%$ higher than the hybrid P30R50H, which did not differ from the hybrid $\mathrm{P} 30 \mathrm{~B} 39 \mathrm{H}$, values below those found by Mendes et al. (2014), which evaluated different nitrogen doses for the hybrid P30R50H, with average grain yield of $12,896 \mathrm{~kg} \mathrm{ha}^{-1}$. Grain yield should not be the only form of evaluation to estimate digestibility and total digestible nutrients, and should analyze the fiber portion of this silage.

In the overall mean, the values of mineral matter, crude protein, neutral detergent fiber, hemicellulose, dry matter intake, and relative silage values did not differ between the different hybrids (Table 2).

Values of neutral detergent fiber of the three hybrids did not differ and were higher than the levels recommended by Neumann et al. (2014) for good quality silage. Values of neutral detergent fiber send the food a higher or lower intake, acting as a limitation of consumption through rumen filling, where high values can result in low consumption of dry matter by animals.

The values of acid detergent fiber differed $(\mathrm{P}<0.05)$ between the hybrids $\mathrm{P} 2530$ and $\mathrm{P} 30 \mathrm{R} 50 \mathrm{H}$, in which the hybrid $\mathrm{P} 30 \mathrm{R} 50 \mathrm{H}$ presented $15 \%$ lower content of acid detergent fiber compared to the hybrid P2530, and both did not differ from the hybrid P30B39H, with 33.10\%. Only the hybrid P30R50H presented values below the recommendations of Neumann et al. (2014), who reported that a good corn hybrid should have a maximum of $32 \%$ acid detergent fiber for a good digestibility of the final food.

The hybrid $\mathrm{P} 30 \mathrm{~B} 39 \mathrm{H}$ did not differ from the others regarding total digestible nutrients (TDN), but the hybrids P2530 and P30R50H differed from each other $(\mathrm{P}<0.05)$, where $\mathrm{P} 30 \mathrm{R} 50 \mathrm{H}$ had $6 \%$ more total digestible nutrients compared to $\mathrm{P} 2530$. These higher values are to the detriment of the lower acid detergent fiber content of the hybrid. 
Table 2

Chemical composition of corn plants harvested at the R5 phenological stage for silage production.

\begin{tabular}{|c|c|c|c|c|c|c|}
\hline Items & P2530 & P30B39H & P30R50H & Mean & $\mathrm{P}>\mathrm{F}$ & $\mathrm{CV}, \%$ \\
\hline & \multicolumn{6}{|c|}{$\%$ in DM } \\
\hline MM & $1,98 \mathrm{a}$ & $2,23 \mathrm{a}$ & $2,18 \mathrm{a}$ & 2,13 & 0,3394 & 9,61 \\
\hline $\mathrm{CP}$ & $4,65 \mathrm{a}$ & $3,92 \mathrm{a}$ & $4,39 \mathrm{a}$ & 4,32 & 0,0762 & 7,46 \\
\hline NDF & $61,56 \mathrm{a}$ & $64,06 \mathrm{a}$ & $62,72 \mathrm{a}$ & 62,78 & 0,9189 & 11,70 \\
\hline $\mathrm{ADF}$ & $35,53 \mathrm{a}$ & $33,10 \mathrm{ab}$ & $30,24 \mathrm{~b}$ & 32,94 & 0,0145 & 7,81 \\
\hline HEM & $26,03 \mathrm{a}$ & $30,96 \mathrm{a}$ & $32,82 \mathrm{a}$ & 29,82 & 0,6307 & 27,75 \\
\hline \multirow[t]{2}{*}{ TDN } & $62,97 \mathrm{~b}$ & $64,68 \mathrm{ab}$ & $66,57 \mathrm{a}$ & 64,77 & 0,0543 & 2,78 \\
\hline & \multicolumn{6}{|c|}{$\%$} \\
\hline \multirow[t]{2}{*}{$\begin{array}{l}\text { DM consumed } \\
\text { (\% Live Weight) }\end{array}$} & $1,99 \mathrm{a}$ & $1,88 \mathrm{a}$ & $1,93 \mathrm{a}$ & 1,93 & 0,8656 & 12,83 \\
\hline & \multicolumn{6}{|c|}{ Mcalkg $^{-1}$ de DM } \\
\hline \multirow[t]{2}{*}{ LlE } & $1,42 \mathrm{~b}$ & $1,46 \mathrm{a}$ & $1,51 \mathrm{a}$ & 1,47 & 0,0257 & 3,07 \\
\hline & \multicolumn{6}{|c|}{ Índex } \\
\hline RVF & $97,0 \mathrm{a}$ & $94,1 \mathrm{a}$ & $99,7 \mathrm{a}$ & 96,9 & 0,8583 & 12,66 \\
\hline
\end{tabular}

DM: dry matter, MM: mineral matter, CP: crude protein, NDF: neutral detergent fiber, ADF: acid detergent fiber, HEM: hemicellulose, TDN: total digestible nutrients, DM consumed: dry matter consumed expressed as \% of live weight, LlE: liquid lactation energy, RVF: relative value of food.

Hybrids $\mathrm{P} 3039 \mathrm{H}$ and $\mathrm{P} 30 \mathrm{R} 50 \mathrm{H}$ showed the highest values of total digestible nutrients and presented the lowest proportion of grains in their physical composition, contrary to the statement by Cañizares, Rodrigues and Cañizares (2009) that a corn hybrid with higher grain concentration in its structure would lead to a silage with higher values of total digestible nutrients, showing the great importance of fiber quality in the hybrid choice.

The net lactation energy showed no difference ( $\mathrm{p}$ $<0.05$ ) for the hybrid P2530, compared to the other hybrids, where the hybrid P30R50H presented 6\% more net lactation energy compared to the P2530. These values are related to a lower acid detergent fiber content and a higher total digestible nutrient value.

With the advancement of the period of grain filling and corn plants, it was found that regardless of the hybrid evaluated, the percentage participation of stem, leaves and bracts plus cob in the plant decreased linearly in the order of $0.22 \% ; 0.30 \%$ and
$0.34 \%$ per day, respectively, while the participation of grains in the plant structure grew linearly by $0.87 \%$ per day (Figure 1 ).

With advance in the physiological maturity of the plant, there is accumulation of grains in the plant, in the order of $0.87 \%$ per day, with a dilution of the other components by $0.22 \%, 0.30 \%$ and $0.34 \%$ per day for stem, leaves and bracts plus cob, respectively, considering the average of the three hybrids. This same behavior was reported by Lavezzo, Lavezzo and Campos et al. (1997).

The daily grain accumulation was higher for the P2530 hybrid, with 28\% higher accumulation than the P30B39H hybrid and 25\% higher than the P30R50H hybrid. The higher grain accumulation rate resulted in a 2.4 times higher stem dilution rate than the hybrid P30B39H, which had the lowest grain accumulation rate and the lowest stem dilution rate. Stem dilution by grain accumulation is important due to the replacement of a low digestibility fiber with a material with better digestibility. 
The hybrid with the highest dilution rate for the component bract plus cob was $\mathrm{P} 30 \mathrm{~B} 39 \mathrm{H}$ with a $37 \%$ higher dilution rate compared to the $\mathrm{P} 30 \mathrm{R} 50 \mathrm{H}$ hybrid, which had the lowest dilution rate $(0.29 \%$ per day). This dilution is essential since this component is made up of a low quality cell wall that leads to decreased nutritive value of silage.

Leaf is one of the components with the best digestibility, however, it is also diluted due to grain accumulation, so it should be considered hybrids with a higher grain accumulation rate and a lower leaf dilution rate. The hybrid with the lowest leaf dilution rate was $\mathrm{P} 30 \mathrm{~B} 39 \mathrm{H}$, followed by the $\mathrm{P} 2530$ hybrid.

In the structural physical composition of the plant, there was a difference $(\mathrm{p}<0.05)$ regarding the participation of stem, leaves, bract plus cob, and grains among the evaluated hybrids. The stem participation in the hybrid P2530 was the lowest, $17 \%$ less when compared to the hybrid $\mathrm{P} 30 \mathrm{~B} 39 \mathrm{H}$. Nussio, Campos and Dias (2001) showed that the stem has a lower digestibility than the whole plant, inferring that a high concentration of this fraction may decrease the digestibility of the resulting silage.

With respect to the leaves in the plant structure at the time of ensiling, the hybrids P30B39H and P30R50H showed no differences from each other, and both differed $(\mathrm{P}<0.05)$ from the hybrid $\mathrm{P} 2530$. In comparison, the hybrid $\mathrm{P} 30 \mathrm{~B} 39 \mathrm{H}$ presented $17 \%$ more leaves than the hybrid $\mathrm{P} 2530$, which presented the lowest leaf participation.

The setbracts plus cob showed lower participation in the hybrids P2530 and P30B39H, which did not differ from each other, but both differed $(p<0.05)$ from the hybrid $\mathrm{P} 30 \mathrm{R} 50 \mathrm{H}$, which presented the largest participation of this component (17\%).

The portion of grains in the plant presented 19\% more in the hybrid P2530, with 51\%, compared to the hybrid P30R50H, presenting differences $(\mathrm{P}<0.05)$ between P2530 and the other hybrids, these data are superior to those reported by Mendes, Gabriel, Faria, Rossi and Possatto (2015), who found 36.4\% grains in the average of four hybrids and $33.2 \%$ and $31.8 \%$ grains for the hybrid $\mathrm{P} 30 \mathrm{~B} 39 \mathrm{H}$, sown in October and November, respectively.

According to the proposals of Neumann et al. (2014), a corn hybrid recommended for silage production must contain in its physical composition less than $25 \%$ bract plus cob, less than $20 \%$ thatch, more than $15 \%$ leaves and a value greater than $35 \%$ grains. With these considerations, we can say that only the hybrid P2530 presented characteristics within the ideal, and the other hybrids presented higher stem proportion than recommended by the above authors.

The dry matter contents in the period of kernel filling until the kernel dent stage, independently of the evaluated hybrid, showed increasing rates, where the hybrid P30R50H obtained the highest dry matter dilution rate for the leaves, and for the bracts plus cobs. For leaves, the hybrid presented $29 \%$ more than the average of the hybrids and for the bracts plus cobs, the hybrid P30R50H showed 19\% more than the average of the hybrids (Table 3 ). According to Zeoula et al. (2003), these components directly impact the digestibility of the fiber fraction, which presents genetic variation between hybrids and has high heritability and the selection of materials with higher cell wall digestibility can be made without influencing grain yield.

Grain dry matter contents (Table 4 ) also showed differences between harvest dates $(p<0.05)$, where the hybrid $\mathrm{P} 30 \mathrm{~B} 39 \mathrm{H}$ presented the largest increase of dry matter for this component, with $4 \%$ more than the general average of the hybrids, $1.12 \%$, which refers to a larger and faster starch deposition. 
Table 3

Percentage of the fractions stem, leaves bract plus cob and grains in the plant physical structure (on a dry matter basis) of corn hybrids for silage production at different reproductive stages.

\begin{tabular}{|c|c|c|c|c|c|}
\hline \multirow{2}{*}{ Hybrids } & \multicolumn{4}{|c|}{ Days after plant emergencies (phenological stage) ${ }^{2}$} & \multirow{2}{*}{ Regression equations ${ }^{1}$} \\
\hline & $\mathrm{R} 2$ & R3 & $\mathrm{R} 4$ & R5 & \\
\hline & \multicolumn{5}{|c|}{ Percentage of stem in plant, \% in DM } \\
\hline P 2530 & 25,5 & 21,3 & 20,5 & 17,0 & $\begin{array}{l}\mathrm{Y}=60,2162-0,3781 \mathrm{D} \\
\mathrm{CV}: 8,9 ; \mathrm{R}^{2}: 0,7432 ; \mathrm{P}=0,0003\end{array}$ \\
\hline P $30 \mathrm{~B} 39 \mathrm{H}$ & 25,0 & 21,1 & 23,7 & 21,6 & $\begin{array}{l}Y=34,3995-0,1114 \mathrm{D} \\
C V: 11,4 ; R^{2}: 0,1180 ; P=0,2743\end{array}$ \\
\hline P $30 \mathrm{R} 50 \mathrm{H}$ & 24,5 & 23,0 & 21,7 & 20,7 & $\begin{array}{l}\mathrm{Y}=41,3681-0,1824 \mathrm{D} \\
\mathrm{CV}: 11,9 ; \mathrm{R}^{2}: 0,2517 ; \mathrm{P}=0,0965\end{array}$ \\
\hline Mean & 25,0 & 21,8 & 22,0 & 19,8 & $\begin{array}{l}\mathrm{Y}=45,3279-0,2240 \mathrm{D} \\
\mathrm{CV}: 11,6 ; \mathrm{R}^{2}: 0,3287 ; \mathrm{P}=0,0003\end{array}$ \\
\hline
\end{tabular}

\begin{tabular}{|c|c|c|c|c|c|}
\hline \multirow[b]{2}{*}{ P 2530} & \multicolumn{5}{|c|}{ Percentage of leaves in plant, $\%$ in DM } \\
\hline & 23,4 & 19,8 & 19,1 & 16,8 & $\begin{array}{l}\mathrm{Y}=49,7490-0,2895 \mathrm{D} \\
\mathrm{CV}: 6,7 ; \mathrm{R}^{2}: 0,7756 ; \mathrm{P}=0,0002\end{array}$ \\
\hline P 30B39 H & 26,0 & 21,1 & 20,8 & 19,6 & $\begin{array}{l}\mathrm{Y}=50,9452-0,2809 \mathrm{D} \\
\mathrm{CV}: 10,8 ; \mathrm{R}^{2}: 0,5083 ; \mathrm{P}=0,0093\end{array}$ \\
\hline P 30R50 H & 26,7 & 21,4 & 20,6 & 19,1 & $\begin{array}{l}Y=56,7047-0,3357 \mathrm{D} \\
C V: 11,6 ; \mathrm{R}^{2}: 0,5595 ; \mathrm{P}=0,0052\end{array}$ \\
\hline \multirow[t]{2}{*}{ Mean } & 25,4 & 20,8 & 20,2 & 18,5 & $\begin{array}{l}\mathrm{Y}=52,4663-0,3021 \mathrm{D} \\
\mathrm{CV}: 10,7 ; \mathrm{R}^{2}: 0,5323 ; \mathrm{P}=0,0001\end{array}$ \\
\hline & \multicolumn{5}{|c|}{ Percentage of bract plus cob in plant, $\%$ in DM } \\
\hline P 2530 & 22,7 & 16,8 & 16,4 & 14,8 & $\begin{array}{l}\mathrm{Y}=53,1114-0,3424 \mathrm{D} \\
\mathrm{CV}: 9,9 ; \mathrm{R}^{2}: 0,7384 ; \mathrm{P}=0,0003\end{array}$ \\
\hline P 30B39 H & 22,8 & 19,4 & 14,8 & 15,2 & $\begin{array}{l}\mathrm{Y}=58,8752-0,3943 \mathrm{D} \\
\mathrm{CV}: 9,7 ; \mathrm{R}^{2}: 0,7885 ; \mathrm{P}=0,0001\end{array}$ \\
\hline P 30R50 H & 22,9 & 19,3 & 16,9 & 17,0 & $\begin{array}{l}\mathrm{Y}=48,7276-0,2871 \mathrm{D} \\
\mathrm{CV}: 8,7 ; \mathrm{R}^{2}: 0,6902 ; \mathrm{P}=0,0008\end{array}$ \\
\hline \multirow[t]{2}{*}{ Mean } & 22,8 & 18,5 & 16,0 & 15,7 & $\begin{array}{l}\mathrm{Y}=53,5714-0,3413 \mathrm{D} \\
\mathrm{CV}: 9,6 ; \mathrm{R}^{2}: 0,7120 ; \mathrm{P}=0,0001\end{array}$ \\
\hline & \multicolumn{5}{|c|}{ Percentage of grains in plant, $\%$ in DM } \\
\hline P 2530 & 28,4 & 42,1 & 43,9 & 51,4 & $\begin{array}{l}\mathrm{Y}=-62,9371+1,0086 \mathrm{D} \\
\mathrm{CV}: 10,5 ; \mathrm{R}^{2}: 0,7972 ; \mathrm{P}=0,0001\end{array}$ \\
\hline P 30B39 H & 26,1 & 38,4 & 40,6 & 43,7 & $\begin{array}{l}Y=-44,0471+0,7852 D \\
C V: 14,1 ; R^{2}: 0,6213 ; P=0,0023\end{array}$ \\
\hline P 30R50 H & 25,9 & 36,2 & 40,9 & 43,1 & $\begin{array}{l}\mathrm{Y}=-46,9567+0,8067 \mathrm{D} \\
\mathrm{CV}: 10,6 ; \mathrm{R}^{2}: 0,7594 ; \mathrm{P}=0,0002\end{array}$ \\
\hline Mean & 26,8 & 38,9 & 41,8 & 46,1 & $\begin{array}{l}\mathrm{Y}=-51,3136+0,8668 \mathrm{D} \\
\mathrm{CV}: 12,7 ; \mathrm{R}^{2}: 0,6716 ; \mathrm{P}=0,0001\end{array}$ \\
\hline
\end{tabular}

1 - D = days after plant emergence, ranging from 93 to 114 .

2 - Escala de desenvolvimento nos estádios reprodutivos: R2 = kernel blister, R3 = kernel milk,

$\mathrm{R} 4=$ kermel dough e R5 = kermel dent.

The whole plant dry matter dilution rate of the the different harvesting stages, and the hybrid with different hybrids showed differences $(p<0.05)$ for the highest whole plant dry matter dilution rate was 
the P2530, with $6 \%$ higher than the average, which was $0.56 \%$, and $17.52 \%$ higher than the hybrid P30B39H, which had the lowest dry matter dilution rate $(0.49 \%)$ in the whole plant. The dilution rate refers to nutrient translocation (Zapollatto et al., 2009), and this can be confirmed by the higher grain yield of the hybrid P2530, which also presented the highest dilution rate.

\section{Table 4}

Dry matter of the components stem, leaves, bracts plus cobs and grains of plants of corn hybrids for silage production at different reproductive stages.

\begin{tabular}{|c|c|c|c|c|c|}
\hline \multirow{2}{*}{ Hybrids } & \multicolumn{4}{|c|}{ Phenological stage $^{2}$} & \multirow{2}{*}{ Regression equations ${ }^{1}$} \\
\hline & $\mathrm{R} 2$ & R3 & $\mathrm{R} 4$ & R5 & \\
\hline & \multicolumn{5}{|c|}{ Dry matter of the components stem, $\%$} \\
\hline P 2530 & 25,7 & 26,7 & 24,8 & 24,9 & $\begin{array}{l}Y=32,0800-0,0633 \mathrm{D} \\
\mathrm{CV}: 7,2 ; \mathrm{R}^{2}: 0,0796 ; \mathrm{P}=0,3743\end{array}$ \\
\hline P $30 \mathrm{~B} 39 \mathrm{H}$ & 22,9 & 22,3 & 23,5 & 21,4 & $\begin{array}{l}\mathrm{Y}=27,1828-0,0447 \mathrm{D} \\
\mathrm{CV}: 8,5 ; \mathrm{R}^{2}: 0,0385 ; \mathrm{P}=0,5411\end{array}$ \\
\hline P 30R50 H & 17,6 & 24,2 & 22,3 & 21,0 & $\begin{array}{l}Y=9,2409+0,1162 \mathrm{D} \\
\mathrm{CV}: 17,7 ; \mathrm{R}^{2}: 0,0656 ; \mathrm{P}=0,4215\end{array}$ \\
\hline \multirow[t]{2}{*}{ Mean } & 22,1 & 24,4 & 23,5 & 22,4 & $\begin{array}{l}Y=22,8346+0,0027 D \\
C V: 13,7 ; R^{2}: 0,0005 ; P=0,9683\end{array}$ \\
\hline & \multicolumn{5}{|c|}{ Dry matter of the components leaves \% } \\
\hline P 2530 & 27,0 & 31,2 & 35,2 & 33,7 & $\begin{array}{l}Y=-3,7190+0,3429 D \\
C V: 7,8 ; R^{2}: 0,5806 ; P=0,0040\end{array}$ \\
\hline P 30B39 H & 28,7 & 31,7 & 37,8 & 37,2 & $\begin{array}{l}Y=-12,8319+0,4509 \mathrm{D} \\
\mathrm{CV}: 7,3 ; \mathrm{R}^{2}: 0,7077 ; \mathrm{P}=0,0006\end{array}$ \\
\hline P 30R50 H & 25,4 & 32,2 & 38,6 & 39,8 & $\begin{array}{l}Y=-39,2919+0,7081 \mathrm{D} \\
C V: 10,6 ; \mathrm{R}^{2}: 0,7384 ; \mathrm{P}=0,0003\end{array}$ \\
\hline Mean & 27,0 & 31,7 & 37,2 & 36,9 & $\begin{array}{l}Y=-18,6157+0,5006 \mathrm{D} \\
C V: 9,7 ; \mathrm{R}^{2}: 0,6166 ; \mathrm{P}=0,0001\end{array}$ \\
\hline & \multicolumn{5}{|c|}{ Dry matter of the components bracts plus cobs, $\%$} \\
\hline P 2530 & 24,8 & 27,6 & 33,4 & 33,2 & $\begin{array}{l}Y=-16,0038+0,4419 D \\
C V: 8,4 ; R^{2}: 0,6971 ; P=0,0007\end{array}$ \\
\hline P 30B39 H & 19,8 & 28,4 & 30,4 & 30,6 & $\begin{array}{l}Y=-23,4809+0,4904 \mathrm{D} \\
C V: 15,9 ; R^{2}: 0,4835 ; P=0,0121\end{array}$ \\
\hline P 30R50 H & 24,2 & 29,9 & 35,6 & 37,7 & $\begin{array}{l}\mathrm{Y}=-36,6405+0,6619 \mathrm{D} \\
\mathrm{CV}: 7,4 ; \mathrm{R}^{2}: 0,8575 ; \mathrm{P}=0,0001\end{array}$ \\
\hline \multirow[t]{2}{*}{ Mean } & 22,9 & 28,6 & 33,1 & 33,8 & $\begin{array}{l}Y=-25,3751+0,5314 \mathrm{D} \\
\mathrm{CV}: 12,3 ; \mathrm{R}^{2}: 0,5789 ; \mathrm{P}=0,0001\end{array}$ \\
\hline & \multicolumn{5}{|c|}{ Dry matter of the components grains, $\%$} \\
\hline P 2530 & 36,7 & 51,8 & 56,2 & 60,3 & $\begin{array}{l}\mathrm{Y}=-59,7900+1,0733 \mathrm{D} \\
\mathrm{CV}: 7,1 ; \mathrm{R}^{2}: 0,8645 ; \mathrm{P}=0,0001\end{array}$ \\
\hline P 30B39 H & 38,4 & 51,6 & 57,7 & 63,5 & $\begin{array}{l}Y=-67,7938+1,1652 \mathrm{D} \\
\mathrm{CV}: 10,5 ; \mathrm{R}^{2}: 0,7658 ; \mathrm{P}=0,0002\end{array}$ \\
\hline P 30R50 H & 40,3 & 51,8 & 60,8 & 63,1 & $\begin{array}{l}\mathrm{Y}=-60,5400+1,1067 \mathrm{D} \\
\mathrm{CV}: 5,8 ; \mathrm{R}^{2}: 0,9017 ; \mathrm{P}=0,0001\end{array}$ \\
\hline Mean & 38,5 & 51,8 & 58,2 & 62,3 & $\begin{array}{l}Y=-62,7079+1,1151 \mathrm{D} \\
C V: 7,8 ; R^{2}: 0,8246 ; P=0,0001\end{array}$ \\
\hline
\end{tabular}


continuation

\begin{tabular}{|c|c|c|c|c|c|}
\hline \multirow[b]{2}{*}{ P 2530} & \multicolumn{5}{|c|}{ Dry matter content of the whole plant, $\%$} \\
\hline & 27,4 & 33,0 & 38,6 & 39,4 & $\begin{array}{l}Y=-26,6781+0,5924 D \\
C V: 5,9 ; R^{2}: 0,8608 ; P=0,0001\end{array}$ \\
\hline P 30B39 H & 25,6 & 33,9 & 34,4 & 36,8 & $\begin{array}{l}Y=-178838+0,4886 \mathrm{D} \\
C V: 9,5 ; \mathrm{R}^{2}: 0,6469 ; \mathrm{P}=0,0016\end{array}$ \\
\hline P 30R50 H & 25,7 & 31,8 & 36,3 & 37,8 & $\begin{array}{l}Y=-27,7624+0,5862 \mathrm{D} \\
\mathrm{CV}: 5,9 ; \mathrm{R}^{2}: 0,8693 ; \mathrm{P}=0,0001\end{array}$ \\
\hline Mean & 26,2 & 32,9 & 36,5 & 38,0 & $\begin{array}{l}Y=-24,1081+0,5557 \mathrm{D} \\
\mathrm{CV}: 7,4 ; \mathrm{R}^{2}: 0,7662 ; \mathrm{P}=0,0001\end{array}$ \\
\hline
\end{tabular}

1 - D = days after plant emergence, ranging from 93 to 114 .

2 - Escala de desenvolvimento nos estádios reprodutivos: R2 = kernel blister, R3 = kernel milk,

$\mathrm{R} 4=$ kermel dough e R5 = kermel dent.

For the stem dry matter dilution rate in the different evaluation dates, there were no changes ( $>0.05$ ) for the dry matter of stems harvested in the different reproductive stages, containing $23.10 \%$ dry matter, in the overall average. According to Zapollatto et al. (2009), the dry matter content of the stem tends to be increasing with the advance of the cycle, which did not occur in the present study.

The stem component presented the lowest dry matter contents in the hybrids $\mathrm{P} 30 \mathrm{R} 50 \mathrm{H}$ and P30B39H, which showed no difference $(p>0.05)$ from each other, but with difference $(p<0.05)$ of both in relation to $\mathrm{P} 2530$, which presented a content of dry matter $18.57 \%$ higher than the hybrid P30R50H. These low dry matter contents indicate that the stem has lower nutrient retention capacity.

Values of leaf dry matter content differed between the three hybrids evaluated, with the hybrid P2530 having the lowest value, 15\% lower than the hybrid P30R50H which presented the highest leaf dry matter content $(39.80 \%)$. Leaves are known to be the fiber portion of the plant that has the highest digestibility. And a higher dry matter content leads to higher nutrient accumulation (Duarte, Kiehl, Camargo, \& Reco 2003). Then, these values should be considered, but it is noteworthy that these leaves should be green and not senescent, which can also increase the dry matter content, however of low digestibility.
In the component bracts plus cob, lower dry matter contents were obtained in the hybrids $\mathrm{P} 30 \mathrm{~B} 39 \mathrm{H}$ and $\mathrm{P} 2530$, not differing $(\mathrm{p}>0.05)$ from each other, but both presented difference $(p<0.05)$ from $\mathrm{P} 30 \mathrm{R} 50 \mathrm{H}$, which presented $38 \%$, and this is $23 \%$ higher than the hybrid $\mathrm{P} 30 \mathrm{~B} 39 \mathrm{H}$ which presented the lowest value.

\section{Conclusions}

The hybrid P30R50H was the most balanced and most suitable for silage production considering the dry biomass production, the fiber composition of the plant and the relative value of the food, among the hybrids evaluated.

The phenological advance provided increase of grains and reduction of the other components in the physical composition of the plant. Kernel dough stage (R4) proved to be the most appropriate stage to recommend harvesting for corn silage production, with better association between silage yield and plant physical composition.

\section{References}

Association of Official Analytical Chemists (1984). Official methods of analysis. (14nd ed.). Washington, D.C.: AOAC.

Association of Official Analytical Chemists (1995). Official methods of analysis. (16nd ed.) Washington, D.C.: AOAC. 
Bolsen, K. K. (1996). Silage technology. Australian Maize Conference, 2,1-30.

Cañizares, G. I. L., Rodrigues, L., \& Cañizares, M. C. (2009). Metabolismo de carboidratos não-estruturais em ruminantes. Archives of Veterinary Science, 14(1), 63-73. doi: 10.5380/avs.v14i1.13615

Comissão de Fertilidade do Solo-RS/SC (1995). Recomendações de adubação e calagem para os estados do Rio Grande do Sul e Santa Catarina. Passo Fundo, RS: Comissão de Química e Fertilidade do Solo- RS/SC.

Duarte, A. P., Kiehl, J. C., Camargo, M. A. F., \& Reco, P. C. (2003). Acúmulo de matéria seca e nutrientes em cultivares de milho originárias de clima tropical e introduzidas de clima temperado. Revista Brasileira de Milho e Sorgo, 2(3), 1-20. doi: 10.18512/19806477/rbms.v2n03p\%25p

Ferrari, E., Jr., Possenti, R. A., Lima, M. L. P., Nogueira, J. R., \& Andrade, J. B. (2005). Características agronômicas, composição química e qualidade de silagens de oito cultivares de milho. Boletim de Indústia Animal, 62(1), 19-27. Recuperado de http://www.iz.sp.gov.br/bia/index.php/bia/article/ view/1312/ 1307

Gabriel, A. (2015). Características agronômicas e bromatológicas da forragem de topcrosses de linhagens $S_{3}$ de milho em diferentes espaçamentos. Dissertação de mestrado, Universidade Estadual Centro Oeste, Guarapuava, PR, Brasil. Recuparado de http:/www.unicentroagronomia.com/imagens/ noticias/ 1472148670_dissertacao_andre_gabriel. pdf

Goering, H. K., \& Van Soest, P. J. (1970). Forage fiber analysis: apparatus reagents, procedures and some applications. Washington: Agricultural Handbook, D.C.

Instituto Agronômico do Paraná (2000). Cartas Climáticas do Paraná. Versão 1.0. Londrina: IAPAR.

Lavezzo, W., Lavezzo, O. E. N. M., \& Campos, O., Neto. (1997). Estádio de desenvolvimento do milho. Efeito sobre produção, composição da planta e qualidade da silagem. Revista Brasileira de Zootecnia, 26(4), 675-682. Recuperado de https://repositorio.unesp. br/bitstream/handle/11449/35635/ WOSA1997XZ 31800007.pdf? sequence $=1 \&$ is Allowed $=y$

Lupatini, G. C., \& Nunes, S. P. (1999). Milho para produção de silagem de qualidade. In Confinamento, pastagens e suplementação para produção de bovinos de corte (pp. 104-124). Santa Maria, RS: UFSM.
Lupatini, G. C., Maccari, M., Zanette, S., Piacentini, E., \& Neumann, M. (2004). Avaliação do desempenho agronômico de híbridos de milho (Zea mays, L.) para produção de silagem. Revista Brasileira de Milho e Sorgo, 3(2), 193-203. doi: 10.18512/1980-6477/ rbms.v3n2p193-203 Recuperado de https://ainfo. cnptia.embrapa.br/digital/bitstream/item/ 104239/1/ Avaliacao-desempenho.pdf

Marafon, F., Neumann, M., Ribas, T. M. B., Reinehr, L. L., Poczynek, M., Bueno, A. V. I., \& Fianco, B. (2015). Análise do efeito da colheita da planta de milho em diferentes estádios reprodutivos e do processamento dos grãos sobre a qualidade da silagem. Semina: Ciência Agrárias, 36(5), 32573268. doi: 10.5433/1679-0359.2015v36n5p3257

Mendes, M. C., Gabriel, A., Faria, M. V., Rossi, E. S., \& Possatto, O., Jr. (2015). Época de semeadura de híbridos de milho forrageiro colhidos em diferentes estádios de maturação. RevistaAgro@mbiente Online, 9(2), 136-142. doi: 10.18227/1982-8470ragro. v9i2.2316.

Mendes, M. C., Walter, A. L. B., Possato, O., Jr., Rizzardi, D. A., Schlosser, J., \& Szeuczuk, K. (2014). Dose de nitrogênio associado a enxofre elementar em cobertura na cultura do milho em plantio direto. Revista Brasileira de Milho e Sorgo, 13(1), 96-106. doi: 10.18512/1980-6477/rbms.v13n1p96-106

Neumann, M. (2011). Parâmetros para análise de qualidade da silagem. Maringá, PR: IEPEC.

Neumann, M., Figueira, D. N., Bumbieris, V. H., Jr., Ueno, R. K., \& Leão, G. F. M. (2014). Ensilagem: estratégias visando maior produção de leite. Anais do Simpósio Brasileiro de Ruminantes Leiteiros, Uberlândia, MG, Brasil, 1.

Neumann, M., Nörnberg, J. L., Leão, G. F. M., Horst, E. H., \& Figueira, D. N. (2017). Chemical fractionation of carbohydrate and protein composition of corn silages fertilized with increasing doses of nitrogen. Ciência Rural, 47(5), 1-7. doi: 10.1590/0103$8478 \mathrm{cr} 20160270$

Nussio, L. G., Campos, F. P., \& Dias, F. N. (2001). Importância da qualidade da porção vegetativa no valor alimentício da silagem de milho. Anais do Simpósio Sobre Produção e Utilização de Forragens Conservadas, Maringá, PR, Brasil.

Oliveira, J. S., Sobrinho, F. S., Pereira, R. C., Miranda, J. M., Banys, V. L., Ruggieri, A. C.,... Auad, M. V. (2010). Potencial de utilização de híbridos comerciais de milho para silagem, na região sudeste do Brasil. Revista Brasileira de Milho e Sorgo, 2(1), 62-71. doi: 10.18512/1980-6477/rbms.v2n01p\%25p 
Paziani, S. F., Duarte, A. P., Nussio, L. G., Gallo, P. B., Mateus, G. P., Freitas, R. S.,... Strada, W. L. (2013). Avaliação de cultivares de milho para produção de silagem no estado de São Paulo na safra 2011/12. Nucleus, 10(3), 135-144. Edição Especial. doi: 10.3738/nucleus.v0i0.918

Pinto, A. P, Lançanova, J. A. C., Lugão, S. M. B., Roque, A. P., Abrahão, J. J. S., Oliveira, J. S.,... Mizubuti, I. Y. (2010). Avaliação de doze cultivares de milho (Zea mays L.) para silagem. Semina: Ciências Agrárias, 31(4), 1071-1078. doi: 10.5433/1679-0359.2010v31 n4p 1071

Ritchie, S. W., Hanway, J. J., \& Benson, G. O. (2003). Como a planta de milho se desenvolve. Potafos: Arquivo Agrônomo, 103(15), 20. Recuperado de http://brasil.ipni.net/ipniweb/region/brasil.nsf/0/ 81A0BBD6E936445D83257AA0003A892E/\$FI LE/Encarte103.pdf

Rossi, E. S., Faria, M. V., Mendes, M. C., Possatto, O., Jr., Neumann, M., \& Jobim, C. C. (2016). Características bromatológicas do grão e forragem de híbridos de milho com diferentes texturas de grãos. Agrária, 11(2), 132-141. doi: 10.5039/agraria.v11i2a5363
SAS Institute (1993). SAS Language reference. Version 6. Cary, NC: SAS Institute Inc.

Van Soest, P. J., Robertson, J. B., \& Lewis, B. A. (1991). Methods for dietary fiber, neutral detergent fiber, and nonstarch polysaccharides in relation to animal nutrition. Journal of Dairy Science, 74(10), 35833597. doi: 10.3168/jds.S0022-0302(91)78551-2

Zapollatto, M., Nussio, L. G., Paziani, S. D. F., Ribeiro, J. L., Sarturi, J. O., \& Mourão, G. B. (2009). Relações biométricas entre o estádio de maturação e a produtividade de híbridos de milho para produção de silagem. Revista Brasileira de Zootecnia, 38(2), 256-264. doi: 10.1590/s1516-35982009000200006

Zeoula, L. M., Beleze, J. R. F., Cecato, U., Jobim, C. C., Geron, L. J. V., Prado, O. D., \& Falcão, A. J. S. (2003). Avaliação de cinco híbridos de milho (Zea mays, L.) em diferentes estádios de maturação. Digestibilidade da matéria seca, matéria orgânica e fibra em detergente neutro da porção vegetativa e planta inteira. Revista Brasileira de Zootecnia, 32(3), 567-575. doi: 10.1590/S1516-35982003000300008 
